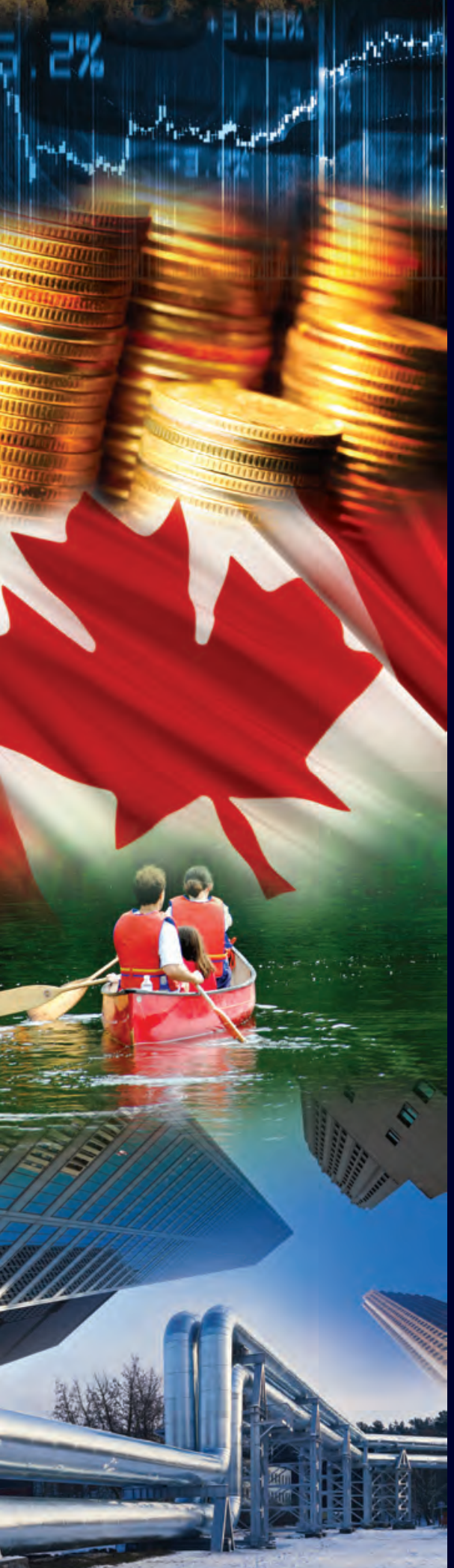

institut C.D. HOWE institute

COMMENTARY

NO. 485

\section{Mortgage Insurance Deductibles: \\ An Idea Whose Time Hasn't Come}

Concerned about the build-up of risk in housing markets, Ottawa is considering introducing mortgage insurance deductibles that would mean lenders share more of the risk of default with mortgage insurers. A better, more effective approach is needed.

Thorsten V. Koeppl and James C. MacGee 


\section{THE C.D. HOWE INSTITUTE'S COMMITMENT TO QUALITY, INDEPENDENCE AND NONPARTISANSHIP}

\section{ABOUT THE AUTHORS}

Thorsten V. Koeppl is Scholar in Financial Services and Monetary Policy, C.D. Howe Institute, and Associate Professor and RBC Fellow, Queen's University.

James C. MacGee is Associate Professor of Economics, Western University.
Commentary No. 485

July 2017

Financial Services and Regulation
The C.D. Howe Institute's reputation for quality, integrity and nonpartisanship is its chief asset.

Its books, Commentaries and E-Briefs undergo a rigorous two-stage review by internal staff, and by outside academics and independent experts. The Institute publishes only studies that meet its standards for analytical soundness, factual accuracy and policy relevance. It subjects its review and publication process to an annual audit by external experts.

As a registered Canadian charity, the C.D. Howe Institute accepts donations to further its mission from individuals, private and public organizations, and charitable foundations. It accepts no donation that stipulates a predetermined result or otherwise inhibits the independence of its staff and authors. The Institute requires that its authors publicly disclose any actual or potential conflicts of interest of which they are aware. Institute staff members are subject to a strict conflict of interest policy.

C.D. Howe Institute staff and authors provide policy research and commentary on a non-exclusive basis. No Institute publication or statement will endorse any political party, elected official or candidate for elected office. The Institute does not take corporate positions on policy matters.
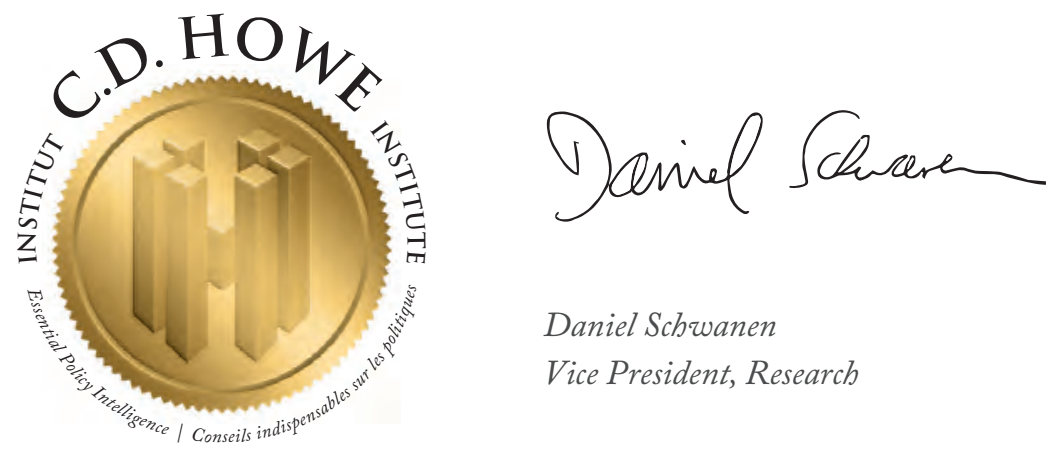

Daniel Schwanen

Vice President, Research 


\section{THE STUDY IN BRIEF}

The rise in house prices - especially in Toronto and Vancouver - has coincided with an increase in the number of homeowners taking on high debt-to-income ratios. This has intensified debate on whether further reforms to mortgage insurance are needed to limit the build-up of risk in housing markets. The focus on mortgage insurance is not surprising, as federally regulated financial intermediaries cannot offer high loan-to-value ( 80 percent or higher) mortgages without mortgage insurance.

A Department of Finance consultation paper (Canada 2016a) is the most recent proposal to reform the mortgage insurance system so as to limit risk build-up in the housing sector. It proposes to introduce a deductible on lenders for insured mortgage losses that would shift a significant amount of potential losses back to mortgage lenders from the insurers. The deductible is intended to address moral-hazard concerns, whereby lenders have an incentive to extend credit to high-risk borrowers if they can shift all of the default risk to mortgage insurers.

In this Commentary, we argue that the proposed deductible is a blunt and ineffective tool to address these concerns. Deductibles need to be capped at relatively modest levels in order to maintain the effectiveness of the mortgage insurance system as a macroprudential tool that insulates the Canadian financial system from the large losses that follow a housing crash. Once passed on to borrowers, such modest values for the deductible imply small increases in mortgage rates for riskier borrowers. This in turn implies that a deductible would have little impact on the problem that mortgage insurance might facilitate lending to some borrowers who are at relatively high risk of defaulting on their mortgages.

A better way of dealing with excessive mortgage lending to high-risk borrowers is to combine a change in the pricing regime for mortgage insurance with continued refinement of the regulation of the mortgage insurance system. Currently, mortgage insurance premiums do not take into account how default risk differs across mortgages beyond the loan-to-value ratio. Charging the lender an insurance premium that takes into account risks associated with idiosyncratic characteristics of the borrower would directly address moral-hazard concerns. This shift to risk-based pricing should be complemented with a continued refinement of regulations for mortgage insurance underwriting to limit further build-up of risks in the housing sector.

C.D. Howe Institute Commentary $($ is a periodic analysis of, and commentary on, current public policy issues. Barry Norris and James Fleming edited the manuscript; Yang Zhao prepared it for publication. As with all Institute publications, the views expressed here are those of the authors and do not necessarily reflect the opinions of the Institute's members or Board of Directors. Quotation with appropriate credit is permissible.

To order this publication please contact: the C.D. Howe Institute, 67 Yonge St., Suite 300, Toronto, Ontario M5E 1J8. The full text of this publication is also available on the Institute's website at www.cdhowe.org. 


\section{The rise in house prices - especially in Toronto and Vancouver - has coincided with an increase in the number of homeowners with high debt-to-income ratios. This has sparked debate on what policies should be adopted to limit the build-up of risk in housing markets, and on how potential losses from mortgage defaults should be distributed.}

It is not surprising that the discussion has once again shifted to the key role mortgage insurers play in Canadian housing finance. Regulations prevent federally regulated financial intermediaries from offering high loan-to-value ( 80 percent or higher) mortgages without mortgage insurance, which has led to government-backstopped insurance covering over half of outstanding mortgage debt (Poschmann 2011). ${ }^{1}$ Since mortgage insurers currently cover most of a lender's costs associated with default, such as mortgage principal and foregone interest payments, insurers are exposed to the bulk of potential losses from a housing crash.

The potential to transfer some of this risk exposure back to mortgage lenders via a deductible is the subject of a recent Department of Finance consultation paper (Canada 2016a), which proposes the introduction of a deductible on lenders for insured mortgage losses, which would reduce the coverage of losses resulting from default covered by mortgage insurers. The deductible is intended to address moralhazard concerns, whereby lenders have an incentive to extend credit to high-risk borrowers if they can shift all of the default risk to mortgage insurers.

In assessing the desirability of a deductible, it is essential to keep in mind the role of the mortgage insurance system in underpinning the stability of housing finance. ${ }^{2}$ Currently, mortgage insurance and its regulatory framework provide ex ante and $e x$ post measures to reduce the likelihood and mitigate the damage caused by a housing crash. Since many high loan-to-value mortgages must be insured, regulation of minimum standards for underwriting mortgage insurance ${ }^{3}$ can discourage the origination of risky mortgages by a wide range of financial institutions. The current system also limits the risk of contagion of a housing crisis to the broader financial sector by containing most of the losses within the

The authors wish to thank Jeremy Kronick for numerous useful discussions, the CMHC (Kevin Wright), John Crean, Ayodola Dahunsi, David Laidler, David Longworth, Finn Poschmann, Kevin Regan, several anonymous reviewers and members of the Financial Services Research Initiative of the C.D. Howe Institute for their comments on earlier drafts. An earlier draft of the Commentary was submitted to the Department of Finance in response to the call for Consultations on Lender Risk Sharing for Government-Backed Insured Mortgages. The authors retain responsibility for any remaining errors.

1 The insured mortgages share of new mortgage originations has been under 50 percent in recent years, which suggests that the insured share of mortgages outstanding should trend downwards. In 2015, however, insured mortgages still accounted for roughly 40 percent of new mortgage originations (Canada 2016a).

2 See Crawford, Meh, and Zhou (2013) for an overview of residential mortgage finance in Canada. MacGee (2010) discusses how mortgage insurance underwriting requirements have helped limit the build-up of high-risk mortgages in Canada, unlike in the United States in the early 2000s.

3 See OSFI's regulatory guideline B-21, http://www.osfi-bsif.gc.ca/eng/fi-if/rg-ro/gdn-ort/gl-ld/pages/b21_let.aspx. 
mortgage insurance sector. Moreover, by promoting resiliency in Canadian housing finance, mortgage insurance supports lending to stabilize the housing market should a crash occur. This is why the federal government backstops the mortgage insurance system, by promising to make good any shortfall on Canada Mortgage and Housing Corporation (CMHC)-insured mortgages and 90 percent of privately insured mortgages should a mortgage insurer run out of capital (Koeppl and MacGee 2015).

The recent rise in the number of households with a high debt-to-income ratio suggests there are grounds for concern about moral hazard by some lenders. In this Commentary, we argue that the proposed deductible is a blunt and ineffective tool to address these concerns. Deductibles need to be capped at relatively modest levels in order to maintain the effectiveness of the mortgage insurance system as a macroprudential tool that insulates the Canadian financial system from the large losses that follow a housing crash. However, modest values for the deductible imply small increases in mortgage rates for riskier borrowers. This in turn implies that a deductible would have little impact on the problem that mortgage insurance might facilitate lending to some borrowers who are at relatively high risk of defaulting.

A better way of dealing with excessive mortgage lending to high-risk borrowers would be to combine a change in the pricing regime for mortgage insurance with continued refinement of the regulation of the mortgage insurance system. Currently, mortgage insurance premiums do not take into account the differing risk between mortgages with the same loan-to-value ratio due to the idiosyncratic risk characteristics of borrowers. This pricing structure differs from insurance products such as auto, home and life insurance, where the premium typically varies with the relevant risk characteristics of the insuree. Charging the lender a premium that takes these risks into account would address any moral-hazard concerns directly. Such an approach, however, would require careful design to avoid complicating the shopping process for borrowers by requiring them to obtain separate quotes from lenders and mortgage insurers. To address this concern, we recommend that premiums based on risk-based pricing be charged directly to lenders as an upfront payment.

This shift to risk-based pricing should be complemented with a continued refinement of regulations surrounding mortgage insurance and underwriting. Although Guidelines B-20 and B-21 of the Office of the Superintendent of Financial Institutions both help limit moral hazard that might arise when lenders and insurers invest too little in verifying relevant information about borrowers or the internal mortgage review process, the rising risks in housing markets point to the need to monitor the prudence of existing mortgagelending practices. A particular concern here is that further refinements of regulatory guidelines ensure that mortgage insurers have access to the reliable information on borrowers that is needed to price their risk of default accurately.

Although regulation of underwriting standards and processes is important, the case is weaker for ad hoc adjustments of underwriting rules for mortgage insurance to limit the origination of higher-risk mortgages. One example of this was the change in the interest rate used to compute the debt-service ratio, which sought to reduce the number of mortgages originated with high loanto-income values. Unlike a risk-based pricing approach, this direction might push more borrowers towards lenders who operate outside the constraints imposed by regulated mortgage insurance, thereby undermining the idea that mortgage insurance can act as a stabilizer in the housing market.

\section{MICRO-VERSUS MACROPRUDENTIAL REGULATION: A TRADE-OFF}

\section{The Case for Deductibles}

Deductibles have long been incorporated in insurance contracts to limit moral hazard. When insurees must bear some of the loss, they have an incentive to avoid 
a loss and to limit associated damages. This is why deductibles are a feature of many insurance products, ranging from automobile to health insurance. A similar logic applies to mortgage insurance. Facing a deductible, a lender has an increased incentive to invest effort in assessing the likelihood that a borrower might default, and to adjust mortgage terms such as interest rates or the loan-to-value ratio to reflect this risk. Deductibles thus can strengthen incentives for lenders to invest in risk management for insured mortgages.

This argument motivates the deductible proposed by a Department of Finance consultation paper (Canada 2016), the objective of which is to reduce moral hazard that leads to the issuing of an increasing number of mortgages to borrowers at high risk of default. Mortgage lenders have an incentive to issue mortgages to such borrowers since they can offload this risk onto mortgage insurers. Such moral hazard can be profitable to lenders if they can charge risky borrowers higher borrowing rates, while insuring the mortgages at the same premium as for low-risk borrowers.

The consultation paper suggests two alternative deductible structures: a first-loss deductible that places a cap on lender's exposure; or a deductible that is a proportion of the total loss incurred in the event of a default. These structures differ in the incentives they offer for mortgage insurers to minimize losses on defaulting mortgages. With a first-loss deductible, a mortgage insurer has little incentive to invest resources to reduce the realized loss to less than the deductible. Such a model thus could result in a conflict of interest between lenders and mortgage insurers as to whether the realized loss on a defaulting mortgage was minimized. ${ }^{4}$ This would remove an attractive feature of the current system of mortgage insurance, which provides insurers a strong incentive to minimize the loss on defaulting mortgages.

This points to the need for a proportional, rather than a fixed, deductible, so as to align the incentive of insurers with that of lenders. Working with the example provided in the Department of Finance consultation document, we can estimate roughly the impact of such a deductible. We first compare the impact of the low- and high-loss examples from the consultation document, which envisions a 20 percent (low) and 50 percent (high) loss upon default on a $\$ 300,000$ mortgage. With a 15 percent (proportional) deductible, the lender's exposure in the event of a default would be $\$ 9,000$ in the low-loss scenario and $\$ 22,500$ in the high-loss case. To compute the impact on the lending interest rate, we need to determine the probability of default. Since the deductible is aimed at high-risk borrowers, we set the probability of default at 5 percent and consider only the high-loss scenario. ${ }^{5}$ The expected loss for the lender would then be $0.05 \times \$ 22,500=\$ 1,125$. This translates into an extra interest rate charge of about 2 basis points (0.02 percent) to cover the cost over the lifetime of a 25-year mortgage, or 10 basis points if one assumes that the cost must be recovered within the 5-year term of a typical mortgage contract. (The extra premium introduced by the deductible approximately scales linearly with the expected loss and the size of the deductible; see Table 1.) If the mortgage interest rate without a deductible were 3 percent, this implies an increase of $\$ 3$ in the monthly payment

4 This argument would lose much of its bite if the first-loss proportion were set at a value that most defaults would exceed. For example, if the first-loss deductible were set at 3 percent and all mortgage defaults saw losses in excess of 5 percent, the incentive for mortgage insurers to minimize losses would be aligned with that of lenders.

5 For comparison, the average default rate for CMHC-insured homeowner mortgages in 2015 was 0.5 percent (see CMHC 2015), although the default rate for high-risk borrowers in an overvalued housing market can be considerably higher. In any case, lower default probabilities would only strengthen our argument. 
Table 1: Impact of a Deductible on Monthly Mortgage Rates

\begin{tabular}{|c|c|c|c|c|}
\hline Mortgage Amount (\$thousands) & 300 & 300 & 300 & 600 \\
\hline Loss given default (\%) & 20 & 50 & 50 & 50 \\
\hline Probability of default (\%) & 5 & 5 & 10 & 10 \\
\hline \multicolumn{5}{|c|}{ Lender Deductible 15\% } \\
\hline Expected loss (\$) & 450 & 1,125 & 2,250 & 4,500 \\
\hline \multicolumn{5}{|l|}{ Expected loss recovered over 5-year term } \\
\hline Impact on borrower - basis points (\$) & $5(\$ 7)$ & $11(\$ 17)$ & $22(\$ 35)$ & $22(\$ 70)$ \\
\hline \multicolumn{5}{|l|}{ Expected loss recovered over 25-year term } \\
\hline Impact on borrower - basis points (\$) & $1(\$ 1)$ & $2(\$ 3)$ & $3(\$ 5)$ & $3(\$ 10)$ \\
\hline \multicolumn{5}{|c|}{ Lender Deductible 50\% } \\
\hline Expected loss (\$) & 1,500 & 3,750 & 7,500 & 15,000 \\
\hline \multicolumn{5}{|l|}{ Expected loss recovered over 5 -year term } \\
\hline Impact on borrower - basis points (\$) & $15(\$ 24)$ & $38(\$ 58)$ & $74(\$ 116)$ & $74(\$ 232)$ \\
\hline \multicolumn{5}{|l|}{ Expected loss recovered over 25 -year term } \\
\hline Impact on borrower - basis points (\$) & $2(\$ 3)$ & $6(\$ 8)$ & $12(\$ 17)$ & $11(\$ 34)$ \\
\hline \multicolumn{5}{|c|}{$\begin{array}{l}\text { Note: Expected loss is calculated as Mortgage amount } \times \text { Loss given default } \times \text { Probability of default } \times \text { Deductible. } \\
\text { Calculations assume a mortgage with a } 5 \text {-year term at } 3 \text { percent with } 25 \text {-year amortization and monthly payments. The } \\
\text { dollar amounts assume that the additional charge on the monthly payment covers the expected loss, taking into account } \\
\text { compounding interest at } 3 \text { percent over the } 5 \text {-year term or the } 25 \text {-year amortization period of the mortgage. For the } \\
\text { extra interest charge, we converted the dollar amounts into a mortgage rate using an amortization table. Amounts are } \\
\text { approximate and subject to rounding errors. }\end{array}$} \\
\hline
\end{tabular}

if amortized over 25 years, or $\$ 17$ if amortized over 5 years. ${ }^{6}$ To affect lending rates significantly, a large deductible and high expected loss would be needed. To see this, consider a $\$ 600,000$ mortgage with an (extremely high) expected default probability of 10 percent and a loss upon default of 50 percent, where the lender faces a 50 percent deductible. This would lead to a sizable premium - roughly 74 basis points over a five-year term, which would translate into higher monthly payments of roughly $\$ 232$. The actual increase in mortgage interest rates due to a deductible likely would fall between these extremes.

6 We assume the lender pays the premium upfront and recovers it over the maturity of the mortgage. This assumes that the lender either keeps the mortgage for the entire time or can recover the remaining cost when the borrower switches out of the initial mortgage. 
Our calculations, however, do not account for two effects. Working against the increase in cost is that a deductible reduces insurers' expected payouts on claims, which should be reflected in lower rates. ${ }^{7}$ Pushing in the opposite direction is a possible increase in the minimum regulatory capital that lenders are required to hold against the exposure created by deductibles. If this additional capital were to increase the cost of lending, this could push up the rate consumers face (Pavlov and Wachter 2017).

The examples above show that large deductibles would be needed to generate significant differences in the rates lenders offer to low- and high-risk borrowers so as to offset the moral hazard created by mortgage insurance. The reason is that lenders can roll the expected extra cost of the deductible into the mortgage amount, which leads to minor increases in the monthly payment so long as the expected deductible cost is small. ${ }^{8}$ Large deductibles are not a feasible option, however, since they would expose the financial system to large losses in the event of a housing crash - which would defeat the macroprudential role of mortgage insurance as a tool to avoid the risk that such a housing crash would lead to a financial crisis.

\section{Drawbacks of Mortgage Insurance Deductibles}

Although a deductible could discourage moral hazard, it would reduce the amount of risk transferred to mortgage insurers. This is important, since insured losses from mortgage default vary substantially over time. During periods when house prices are rising, mortgage defaults are rare and losses are generally modest. As recent crises in the
United States and Ireland illustrate, however, in a house crash defaults and losses spike. This means that in most years insurers can expect relatively modest payouts, while facing a small probability of incurring very large losses. This is often referred to as mortgage insurers' facing aggregate risk.

This fact - combined with large levels of mortgage debt - implies that losses from a large fall in house prices coinciding with high unemployment would pose a systemic risk to the Canadian financial system. Indeed, this is precisely the federal government's motive for backstopping mortgage insurance by reinsuring against the default of an insurer (see Koeppl and MacGee 2015). ${ }^{9}$ Should a severe housing crash take place, a portion of the losses would flow back to financial institutions whose financial position would already have been weakened by the crisis. Moreover, a housing crash can develop a self-reinforcing dynamic, whereby large losses due to mortgage defaults weaken the financial system and lead to a restriction of access to credit for prospective new homebuyers. By reducing demand for housing, this can deepen the fall in house prices, amplifying the losses from mortgage defaults. These channels of contagion would threaten the stability of the entire financial sector and its lending activities.

A deductible could also increase the cyclical volatility of housing markets. During an upswing in the housing market, the likelihood of default is small and losses are negligible, so that a deductible would have no bite. In a market downturn, however, the expected cost of a deductible for lenders is high, so they would have an incentive to withdraw from lending, which once again goes against the very idea

7 This channel likely would be dampened by the counterparty risk that mortgage insurers would face due to the risk that lenders would be unable to make their deductible payments in the event of a housing crash.

8 This point is recognized in the Department of Finance consultation document, which suggests the impact on rates would be in the range of 20-30 basis points for a five-year mortgage (Canada 2016a, 16).

9 Geithner (2017) argues that some form of government backstop plays an essential role in containing the economic costs of large economic crises. 
of mortgage insurance as a tool to stabilize lending in a systemic housing crisis.

These concerns imply that the deductible share would have to be kept at a relatively modest level to avoid destabilizing Canadian housing finance and the financial system as a whole in a housing crash. This in turn implies that the quantitative impact of a deductible on the lending rate for risky borrowers would be very small, and that a deductible would not be effective in discouraging lending to risky borrowers.

Furthermore, incorporating a deductible in the current system of housing finance would create additional administration costs. Since the securitization of mortgages via the National Housing Act Mortgage-Backed Securities (NHA $\mathrm{MBS}$ ) program relies on the underlying mortgages being free of the risk of default, the Department of Finance proposes that all insurance payments initially be covered by the insurer. To be compatible with the NHA MBS program, the consultation document proposes that insurers recover the deductible through fees levied periodically (perhaps quarterly) on the mortgage originator. In addition to higher administration costs, this would create a risk exposure for insurers should the lender become insolvent. This raises questions of whether mortgage insurers would pull back from dealing with some lenders if a period of high mortgage defaults led to concerns about the solvency of lenders.

There could also be an adverse impact on competition in the mortgage market. Mortgage finance companies and smaller, more specialized lenders often rely on access to mortgage insurance to refinance and to target borrowers with less than a 20 percent down payment. ${ }^{10}$ Hence, deductibles might skew the competition in the mortgage market in favour of more diversified traditional lenders with stronger balance sheets, as was reflected in equity markets upon the announcement of the consultation (see Alexander 2016).

A final concern is that the deductible model could reduce risk sharing across regions. Although the current policy concern centres on a broad-based housing crash, smaller cities face the risk of local economic shocks - such as the failure of a major employer - that adversely impact local housing markets. By exposing local lenders to a share of the resulting losses, a deductible policy could weaken these lenders at a moment of vulnerability.

\section{Is THERE A BeTter Alternative?}

Recent years have seen an increase in the number of mortgages issued to borrowers with very high debt-to-income ratios (see Bank of Canada 2016). This has occurred even though the Department of Finance repeatedly has tightened the rules on mortgage lending by limiting the maximum length of amortization, the maximum loan-to-value ratio, and the calculation of debt-service ratios for obtaining mortgage insurance. Thus, it is natural that the department - and CMHC - should look for alternative policies that might discourage the buildup of risk in the housing market.

We question, however, the effectiveness of the proposed deductible in addressing these concerns. This leads us to offer two alternative options. One is to adopt risk-based pricing of mortgage insurance. Such pricing could be imposed directly on borrowers within the existing framework or, alternatively, introduced by charging mortgage originators directly and relying on pass-through to borrowers through mortgage interest rates. This risk-based pricing should be augmented with the fine-tuning of regulations to ensure that lenders and mortgage insurers have the information and

10 Mortgage finance companies have a growing share of the Canadian market, and typically rely on being able to securitize their mortgages; see Coletti, Gosselin, and MacDonald (2016). 
risk-management capacity they need to evaluate the risks they incur. The second option is to tighten insurance and lending rules further so as to exclude some prospective borrowers with high-risk characteristics. A recent example that targets such borrowers directly is the change in the qualifying interest rate used to calculate debt-service ratios.

\section{Risk-based Mortgage Insurance Pricing}

Risk-based pricing of mortgage insurance would target moral-hazard concerns directly. With risk-based pricing, lenders would find lending to borrowers with a high risk of default less attractive since they would be required to pay a higher insurance premium. This would remove the distortion implied by the current system, where the premiums charged by $\mathrm{CMHC}$ and its private competitors vary only with the loan-tovalue ratio of the mortgage at origination. ${ }^{11}$

A risk-based pricing system would see the mortgage insurer develop a quantitative model that links a borrower's characteristics (such as loan to income ratio or credit score) to the risk of default. ${ }^{12}$ Hence, such a pricing system could be built on existing credit-scoring models lender use to assess default risk. Developing reasonable risk-assessment models for mortgages is feasible since the underlying risk factors for default are well-documented and transparent to the mortgage originator and insurer so long as sufficient information is included with the insurance application. ${ }^{13}$

The pricing system could be implemented by moving from the current regime, where the price borrowers pay varies only by their loan-to-value ratio, to one where borrowers obtain price quotes from mortgage insurers for each loan application. This would lead to a much larger increase in costs for high-risk borrowers than would a deductible, since the premium would incorporate the entire expected loss. To increase its impact, the borrower could be required to bear the insurance premium up front in cash, rather than roll it into the mortgage itself, as is currently the case. Mortgages for highrisk borrowers thus would become more expensive as they would reflect the default risk in a direct and transparent way. ${ }^{14}$

Such risk-based pricing of mortgage insurance could, however, complicate the shopping experience for prospective borrowers. Borrowers would need to get two quotes when taking out a mortgage, one from the lender for the mortgage interest rate and another from a mortgage insurer. This could increase

11 The level of premiums ranges from 0.6 percent of the mortgage value for loans below 65 percent of value up to 4.50 percent for the smallest down payments. In the mortgage insurance market, CMHC acts as a price leader, with Genworth and Canada Guaranty following by setting comparable premiums.

12 Some of these features influence whether a mortgage is eligible for insurance. In particular, there are ceilings on borrowers' debt-service ratios and on the loan-to-value ratio and property value. For more information, see Canada (2016b).

13 Although there is evidence that lenders hold some "soft information" on the quality of borrowers that is hard to communicate to mortgage insurers, many mortgages are evaluated by lenders solely on the basis on information in the loan application. Using data from the US housing boom, Keys, Seru, and Vig (2012) find that the default risk of both securitized and non-securitized (held by lenders) mortgages with full documentation was similar - suggesting that soft information about borrowers' characteristics was quantitatively unimportant. They find, however, that, for low-documentation mortgages - where the information lenders obtained from interactions with borrowers differed from the documented information there was a significant moral hazard problem, with lenders taking on higher-risk borrowers whom they could securitize and sell off to investors.

14 Risk-based pricing would not apply to low loan-to-value mortgages where the lender takes out (and pays for) insurance in order to refinance mortgages through securitization. 
the cost of searching for a mortgage and potentially discourage competition in the marketplace. ${ }^{15}$

An alternative would be to charge lenders, rather than borrowers, for insurance premiums. Under this scheme, insurers would charge lenders a differential fee up front, based on the risk of the mortgage and the past performance of the lender. Consequently, borrowers would need to shop only for mortgage interest rates, and insurance premiums would be priced into the interest rate, as mortgage lenders would have an incentive to pass on to borrowers any up-front costs of a mortgage. By charging lenders up front, such a scheme would also remove any concerns about a lender's ability to make good on deductible charges for mortgages that default during a period of market stress.

One practical challenge facing this approach is that mortgage insurance currently covers losses on a mortgage throughout its entire maturity. Charging the lender up front would make shortterm mortgages less attractive, and both borrowers and lenders might attempt to game the system by levering up with every renewal without facing new mortgage charges. These concerns could be less relevant, however, if one believes that defaults are most likely and most costly within the first few years of a mortgage. Lenders could also claw back some of the premium costs by adding provisions in the mortgage contract should a borrower switch to a new lender after its term.
Another solution to these challenges would be to adopt a hybrid model where lenders and borrowers each face a mortgage insurance charge. In this system, borrowers would face a fee schedule based on their loan-to-value ratio. The fee for this insurance would be based on the risk after the first five-year term, and thus cover the cost of mortgage insurance when borrowers renew their mortgage. Lenders would be charged a premium based on the cost of insurance for the first five-year term of the mortgage. ${ }^{16}$ This system thus might fit more naturally with existing practices in Canadian housing finance, while mitigating moral-hazard concerns.

\section{Is There a Case for Location-Specific Risk Pricing?}

Although we see the case for increased riskbased pricing of borrower-specific default risk, the case for pricing city- or region-specific risk is less clear. The geographical location of a property does affect the default risk, but the net impact of pricing geographical risk on the stability of regional housing markets is ambiguous. ${ }^{17}$ As a macroprudential tool, we would like to see mortgage insurance premiums react procyclically to housing market conditions, rising during episodes of extraordinary house price increases. Similarly, premiums should react countercyclically with the overall economy, where economic downturns increase the likelihood for default but also lead to lower mortgage rates.

15 Research has found that the shopping effort borrowers make affects the rates they are offered by lenders (see, for example Allen, Clark, and Houde 2014). As a result, if the increased cost of shopping for mortgage quotes led borrowers to reduce their search effort, one might expect quoted rates to rise. Another practical concern is that some lenders might charge different interest rates depending on which insurers borrowers choose, which would further complicate the comparison of total costs among lenders.

16 This structure would restrict new borrowers to an initial mortgage term of five years. Shorter-term mortgages could be accommodated within this framework, but would require a higher interest rate so as to allow the lender to recover the cost of mortgage insurance.

17 Areas that are likely to face weaker economic prospects also might face higher future default rates. Research has found a relationship between cyclical variation in unemployment and bankruptcy in Canada; see, for example, Fieldhouse, Livshits, and MacGee (2012). 
The main reason for pricing location-specific default risk, therefore, is that it could help dampen the appreciation of house prices during regional housing booms. Areas that experience a boom might be exposed to higher risk of a large decline in prices should a market correction occur, and lenders likely would face larger losses in such areas. If mortgage insurers were to incorporate this risk of future losses into region-specific mortgage insurance premiums, the resulting rise in premiums during a housing boom would dampen housing demand.

The effectiveness of this type of regional-based cyclical pricing depends, however, on the persistence of shocks to local economic conditions. Consider, for example, the effect of an extended period of low oil prices on a region such as Alberta, where that sector makes up a large share of the economy. If low prices persist, a period of slow regional economic growth is likely, and the risk of defaults in the region will also likely remain high over that time. As well, the higher mortgage insurance premiums that would prevail during the period of slow economic growth could exacerbate the fall in local house prices.

Thus, if regional shocks are persistent, locationspecific pricing might amplify, rather than dampen, shocks to local housing markets and economic conditions. Moreover, since mortgage insurance acts to share regional risks across home buyers nationally, one is left with a weak case for geographical pricing.

\section{An Alternative: Tighten Underwriting Conditions for Mortgage Insurance}

Why has risk-based pricing not yet been adopted for mortgage insurance? One reason might be that the current pricing system is due to inertia from earlier periods, when higher costs of data analysis limited the implementation of sophisticated pricing. Another possible explanation is that public opinion makes it difficult - especially for a Crown corporation such as $\mathrm{CMHC}$ - to charge premiums that differ according to borrowers' characteristics such as their credit score.
If risk-based pricing proves politically difficult to adopt, a different approach might be to rely on existing tools to limit moral hazard. The recent move to regulate the interest rate used in calculating the debt-service ratio for qualifying mortgages offers one example. This is based on the premise that, under the current mortgage system, some lenders offer relatively risky borrowers low interest rates to allow them to meet the minimum debtservice ratio. By increasing the interest rate used in this calculation, this regulation seeks to reduce the number of mortgages issued with a high debt-toincome ratio. Other measures, such as increasing down-payment requirements, maximum refinancing amounts, or the length of amortization, could also be adopted.

The recent regulatory change has worked to some degree, but we see a shift to risk-based pricing as superior. First, it would tackle the flat-fee mortgage insurance system's moral-hazard problem by giving lenders an incentive to offer interest rates that reflect borrowers' default risk. Second, this approach could encourage competition in the marketplace. If premiums were charged to mortgage originators, borrowers could expect to be assessed according to their relevant risk characteristics when shopping for a mortgage. Finally, we see risk-based pricing as less likely to encourage borrowers to migrate to lenders outside the mortgage insurance system - an important consideration, since the effectiveness of the system as a macroprudential instrument would be diminished by a rise in the share of lending occurring in the non-insured space.

\section{MORTGAGE INSURANCE: THE WAY FORWARD}

The continuing rise in house prices and in the number of homeowners with high debt-to-income ratios suggests an ongoing buildup of risk in Canadian housing markets. The Department of Finance's recent review of mortgage insurance (Canada 2016) is warranted and timely, but we 
do not believe that its focus on introducing a deductible is an effective approach to deal with these concerns. The most direct approach to reducing risk-taking by mortgage lenders would be through the strengthening of minimum lending standards and the adoption of risk-based pricing of mortgage insurance premiums. Such premiums would take into account features of mortgage contracts that are relevant for default, and target the riskiest transactions. Although this would be a seismic shift from past practices, it would be an efficient way to address moral hazard in insured mortgage origination. 


\section{REFERENCES}

Alexander, Doug 2016. "End of Canada's 'unique' mortgage system means higher bank costs." Financial Post, October 5.

Allen, Jason, Robert Clark, and Jean-François Houde. 2014. "The Effect of Mergers in Search Markets: Evidence from the Canadian Mortgage Industry." American Economic Review 104 (10): 3365-96.

Bank of Canada. 2016. Financial Stability Review December 2016. Ottawa.

Canada. 2016a. Department of Finance. "Balancing the Distribution of Risk in Canada's Housing Finance System." Ottawa. Available online at https://www. fin.gc.ca/activty/consult/lrs-prp-eng.pdf.

__ 2016b. Department of Finance. “Technical Backgrounder: Mortgage Insurance Rules and Income Tax Proposals.” Ottawa, October 14. Available online at https://www.fin.gc.ca/n16/ data/16-117_2-eng.asp.

CMHC (Canada Mortgage and Housing Corporation). 2015. Why Housing Matters: Annual Report 2015. Ottawa. Available online at https://www.cmhcschl.gc.ca/en/corp/about/core/upload/annualreport-2015.pdf.

Coletti, Don, Marc-André Gosselin, and Cameron MacDonald. 2016. "The Rise of Mortgage Finance Companies in Canada: Benefits and Vulnerabilities." Financial System Review (December 2016): 39-52.

Crawford, Allan, Césaire Meh, and Jie Zhou. 2013. "The Residential Mortgage Market in Canada: A Primer." Financial System Review (December 2013): 53-63.
Fieldhouse, David, Igor Livshits, and James MacGee. 2012. "Income Loss and Bankruptcies over the Business Cycle." Report for the Office of the Superintendent of Bankruptcy. Available online at http://www.ic.gc.ca/eic/site/bsf-osb.nsf/eng/request. html?Open\&id=AC277EEEE5F0088085257B4800 71B243\&p=1.

Geithner, Timothy. 2017. "Are We Safe Yet? How to Manage Financial Crises." Foreign Affairs, January/ February.

Keys, Benjamin, Amit Seru, and Vikrant Vig. 2012. "Lender Screening and the Role of Securitization: Evidence from Prime and Subprime Mortgage Markets." Review of Financial Studies 25 (7): 2071108.

Koeppl, Thorsten V., and James C. MacGee. 2015. Mortgage Insurance as a Macroprudential Tool: Dealing with the Risk of a Housing Market Crash in Canada. Commentary 430. Toronto: C.D. Howe Institute. July.

MacGee, James. 2010. "Not Here? Housing Market Policy and the Risk of a Housing Bust." E-Brief. Toronto: C.D. Howe Institute. August 1.

Pavlov, Andrey, and Susan Wachter. 2017. "When RiskSharing Increases Risk: Analysis of the Government of Canada Mortgage Risk-Sharing Proposal.” Mimeo.

Poschmann, Finn. 2011. What Governments Should Do in Mortgage Markets. Commentary 318. Toronto: C.D. Howe Institute. January. 


\section{ReCent C.D. Howe institute Publications}

July 2017 Sands, Christopher. "Table Stakes: Congress Will Be Sitting across from Canada at the NAFTA 2.0 Negotiations.” C.D. Howe Institute E-Brief.

July 2017 Genest-Grégoire, Antoine, Luc Godbout, and Jean-Herman Guay. The Knowledge Deficit about Taxes: Who It Affects and What to Do About It. C.D. Howe Institute Commentary 484.

June 2017 Ciuriak, Dan. “Understanding CETA: An Upgrade for Canada’s Global Connections.” C.D. Howe Institute Verbatim.

June 2017 Robins, Steven. “Adding More Juice: How Private Investors can Improve the Performance of Provincial Power Assets.” C.D. Howe Institute E-Brief.

June 2017 Robins, Steven. Banking on Infrastructure: How the Canada Infrastructure Bank can Build Infrastructure Better for Canadians C.D. Howe Institute Commentary 483.

June 2017 Robins, Steven. “Casting Off: How Ottawa Can Maximize the Value of Canada's Major Ports and Benefit Taxpayers." C.D. Howe Institute E-Brief.

June 2017 Kronick, Jeremy. Spendthrifts and Savers: Are Canadians Acting Like they are "House Poor" or "House Rich"? C.D. Howe Institute Commentary 482.

May 2017 Laurin, Alexandre, and Kevin Milligan. Tax Options for Childcare that Encourage Work, Flexibility, Choice, Fairness and Quality. C.D. Howe Institute Commentary 481.

May 2017 Blomqvist, Åke, and Colin Busby. The Paradox of Productivity, Technology, and Innovation in Canadian Healthcare. C.D. Howe Institute Commentary 480.

May 2017 Matthews, Lesley. How to Restore Public Trust and Credibility at the National Energy Board. C.D. Howe Institute Commentary 479.

May 2017 Church, Jeffrey. Defining the Public Interest in Regulatory Decisions: The Case for Economic Efficiency. C.D. Howe Institute Commentary 478.

May 2017 Robson, William B.P., and Alexandre Laurin. "Premium Compensation: The Ballooning Cost of Federal Government Employees.” C.D. Howe Institute E-Brief.

avril 2017 Busby, Colin, Aaron Jacobs, et Ramya Muthukumaran. Besoin d'un rappel? Comment améliorer la couverture vaccinale des enfants au Canada. Institut C.D. Howe commentaire 477.

\section{SUPPORT THE INSTITUTE}

For more information on supporting the C.D. Howe Institute's vital policy work, through charitable giving or membership, please go to www.cdhowe.org or call 416-865-1904. Learn more about the Institute's activities and how to make a donation at the same time. You will receive a tax receipt for your gift.

\section{A REPUTATION FOR INDEPENDENT, NONPARTISAN RESEARCH}

The C.D. Howe Institute's reputation for independent, reasoned and relevant public policy research of the highest quality is its chief asset, and underpins the credibility and effectiveness of its work. Independence and nonpartisanship are core Institute values that inform its approach to research, guide the actions of its professional staff and limit the types of financial contributions that the Institute will accept.

For our full Independence and Nonpartisanship Policy go to www.cdhowe.org. 

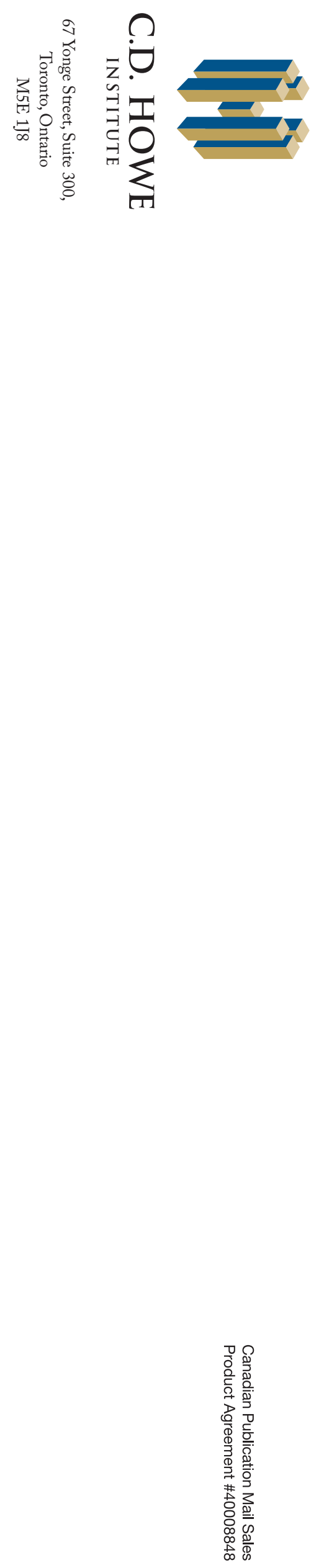